\title{
Patient's Behaviour with Coronary heart desease Viewed from Socio-Cultural aspect of Aceh Society in Zainoel Abidin Hospital
}

\author{
Marniati $^{*}$, Soekidjo Notoatmodjo ${ }^{2}$, Sutomo Kasiman ${ }^{1}$ and $R$ kintoko Rohadi ${ }^{1}$ \\ 1Faculty of Public Health, University of Sumatera Utara \\ ${ }^{2}$ Universitas Indonesia
}

\begin{abstract}
Coronary heart disease (CHD) is a chronic inability of heart to draw an adequate blood on myocardium due to specific problem in coronary artery. When the artery that supplies myocardium is interrupted, thus the heart is unable pumping the blood effectively to fill up an adequate blood perfusion to vital organs and other peripheral tissues. If the perfusion is impaired in time of oxygenation, the patient will threatened by a sudden death. This is a quantitative, analytical and observational research with a design of case study control, in which the subject is CHD patients and the control is non-CHD patients. The research populations were 2318 outpatients with CHD who visited Heart Polyclinic at Zainoel Abidin Hospital Banda Aceh. The sample studied were 92 patients with CHD and 92 patients with non-CHD (control). We used primary and secondary data that processed through editing, coding, entry, cleaning and tabulating. The data was analyzed using univariate, bivariate and multivariate analysis. The results showed that the CHD occurrences are significantly influenced by eating behavior $(p=0,000)$, smoking habit $(p=0,000)$ and sporting habit $(p=0,000)$. Therefore, health workers are expected to increase health promotion in order to improve the quality of life of people, especially in elderly people, by adopting a healthy lifestyle and avoiding CHD risk factors. Moreover, people are also suggested to take regular lipid profile check up and keep off smoking habit in order to do early prevention of CHD.
\end{abstract}

\section{Introduction}

World Health Organization (WHO) estimated that about $50 \%$ of global populations die from heart and blood vessel diseases each year. According to World Health Statistic Report 2008, 17.3 million of the deaths were caused by Cardiovascular Disease (CVD), representing $30 \%$ of all global deaths. Of these deaths, an estimated 7.4 million were due to coronary heart disease and 6.7 million were due to stroke. These deaths are predicted to continue to increase up to 23.4 million people in 2030 . Over $80 \%$ of CVD deaths take place in low- and middle-income countries and more than a half of the deaths were nearly equal 
between men and women. Therefore, it has been recognized as the number one killer and causing disability in the world [24].

Heart disease is also the leading cause of the death in America. Each year, 478.000 people die from Coronary Heart Disease (CHD), 1.5 million people have heart attack, 407.000 people experience heart surgery and other 300.000 people undergo an angioplasty. In 2010, the prevalence of CHD was greatest among persons aged $\geq 65$ years $(19.8 \%)$, followed by those aged $45--64$ years $(7.1 \%)$ and those aged $18--44$ years $(1.2 \%)$. CHD prevalence was greater among men $(7.8 \%)$ than women $(4.6 \%)$, however the prevalence will be drastically accelerate in postmenopausal women (CDC, 2011). According to American Heart Association (AHA) in Heart Stroke Statistic 2010, it was indicated that every 25 seconds, someone will have coronary event and every one minute one will die [4].

The deaths caused by CHD occurrences in Indonesia are also high, approximately reach 26\%. According to National Household Health Survey, it continues to increase within the last 10 years. In 1991, the death rates from CHD were $16 \%$ and significantly increased in 2001 to $26.4 \%$. In 2007, the rate was more than double, growing to $59.5 \%$. According to the Basic Health Research (Riskesdas) 2013 issued by Health Research and Development Agency of Health Ministry of Indonesia, the prevalence of CHD based on interview diagnosed by doctor was $0.5 \%$ while based on doctors diagnose or symptom was $1.5 \%$. The mortality rate due to the disease in Indonesia reached 7.6 million people per year, while the number of patients of all ages were also significantly increased, from 10,600 people in 2010 to 12.800 in 2013 [12].

In a research conducted by Ismail et al. [10] to men and women 14-45 years of age in the South Asia region stated that the risk of myocardial infarct for active smoking was 3.82 higher compared to the control group ( $\mathrm{OR}=3.82 ; 95 \%$; $\mathrm{CI}=1.47-9.94)$, while for those with an increased serum cholesterol was 1.67 higher than the control group $(\mathrm{OR}=1.67$; $95 \%$; $\mathrm{CI}=1.4-2.45$ ). In addition, another research conducted by Smeltzer and Bare [23] found that the CHD risk is substantially increased for 2-4 times in smokers compared to the never smokers. Smoking will reduce the oxygen supply to the heart and body which in turn led to the raise of blood pressure and pulse rate, reduce the cholesterol level (HDL), cause the blood clot to form and damage the endothelial cells. To reduce the risk of CHD, people are recommended to do exercise for about 30 minutes per day. In the research conducted by Harvard Alumni Study in Lipoeto [17] it clearly proved that physical activity/exercise (even in a short term) can significantly reduce CHD risk as it increases the HDL concentration. Women with less physical activity face higher risk of it.

\section{Conceptual Framework}

Conceptual framework is a relationship framework among concepts or variables to be studied. Variable is a characteristic that attached to population which is varied from one to another and is investigated in a research. The variables in this research comprised of CHD occurrence (as dependent variable) and dietary, smoking and sporting habit (as independent variables). The conceptual framework of this research is presented as follow: 
Independent variable (X)

Behaviors viewed from Aceh society culture:

1. Eating behavior

2. Smoking habit

3. Sport
Dependent variable (Y)

\section{CHD occurrences}

Fig. 1. Conceptual framework of this research

\section{Research Methodology}

This is a quantitative, analytical and observational research with a design type of case study control, in which the subject is CHD patients and the control is non-CHD patients [15].

This research was conducted in Zainoel Abidin Hospital Banda Aceh from November 2014 to September 2015, began with preliminary research and ended with final oral exam. The populations in this study were 2318 outpatients with CHD who visited Heart Polyclinic at Zainoel Abidin Hospital Banda Aceh. The size of samples needed in this research was determined using the following formula:

$n=\frac{Z^{2}{ }_{1-\alpha / 2} P(1-P) N}{d^{2}(N-1)+Z^{2}{ }_{1-\alpha / 2} P(1-P)}$

where $\mathrm{P}$ denotes the subject proportion of previous researches that equals to $0.5, \mathrm{~d}$ is the precision level of $0.1, \mathrm{Z}$ is the level of trust of $1.96, \mathrm{n}$ is the number of samples, and $\mathrm{N}$ is the number of population of 796 .

$$
\begin{aligned}
& n=\frac{(1.96)^{2} 0.5(1-0.5) 2319}{(0.1)^{2}(2319-1)+(1.96)^{2} 0.5(1-0.5)} \\
& n=92,26 \text { people }=92 \text { people }
\end{aligned}
$$

The samples to be studied are 92 CHD patients and 92 non-CHD patients (control). The sampling method used was simple random sampling.

The inclusive criteria of the samples are: (1) CHD outpatients who hospitalized at Heart Polyclinic of Zainoel Abidin Hospital Banda Aceh; (2) patients aged >30 years; (3) able to write and read; and (4) willing to participate as respondent. While the exclusive criteria are: (1) CHD patients hospitalized at Heart Polyclinic of Zainoel Abidin Hospital Banda Aceh with complication of heart and kidney failure; and (2) A drastically decreased on health status.

\subsection{Operational Defination}

Below are the operational definitions of the studied variables in this research. 
Table 1. Operational definitions of the studied variables

\begin{tabular}{|c|c|c|c|c|c|}
\hline $\begin{array}{l}\mathbf{N} \\
\mathbf{0 .}\end{array}$ & Variable & $\begin{array}{c}\text { Operational } \\
\text { Definition }\end{array}$ & $\begin{array}{c}\text { Measureme } \\
\text { nt Scale }\end{array}$ & $\begin{array}{c}\text { Measureme } \\
\text { nt Manner }\end{array}$ & Category \\
\hline \multicolumn{6}{|c|}{ Independent Variable } \\
\hline 1 & Behavior & $\begin{array}{l}\text { The CHD patients' } \\
\text { response or reaction to } \\
\text { the CHD occurrence } \\
\text { which is viewed from } \\
\text { Aceh society culture, } \\
\text { encompassing dietary, } \\
\text { smoking and sporting } \\
\text { habit. }\end{array}$ & & & \\
\hline 2 & $\begin{array}{l}\text { Eating } \\
\text { behavior }\end{array}$ & $\begin{array}{l}\text { The eating/drinking } \\
\text { habit of meals and } \\
\text { beverages which } \\
\text { contain saturated fat, } \\
\text { like meat, offal, egg, } \\
\text { milk, etc., that } \\
\text { consumed daily in a } \\
\text { period of time. }\end{array}$ & Ordinal & $\begin{array}{c}\text { Questionnair } \\
\text { esand } \\
\text { interview }\end{array}$ & $\begin{array}{l}\text { 1. Frequently, } \\
\text { everyday - } 3 \\
\text { times a week. } \\
\text { 2. Moderate, } 1 \text { - } \\
2 \text { times a } \\
\text { week. } \\
\text { 3. Infrequently, } \\
\text { once a week } \\
\text { or never. }\end{array}$ \\
\hline 3 & $\begin{array}{l}\text { Smoking } \\
\text { habit }\end{array}$ & $\begin{array}{l}\text { The habit/behavior of } \\
\text { smoking cigarretes or } \\
\text { ever smoking which is } \\
\text { measured from the } \\
\text { number of cigarretes } \\
\text { consumed per day. }\end{array}$ & Ordinal & $\begin{array}{c}\text { Questionnair } \\
\text { esand } \\
\text { interview }\end{array}$ & $\begin{array}{l}\text { 1. Heavy } \\
\text { smoker }(>20 \\
\text { cigarretes a } \\
\text { day). } \\
\text { 2. Moderate } \\
\text { smoker (10- } \\
20 \text { cigarretes } \\
\text { per day). } \\
\text { 3. Light smoker } \\
\text { (<10 } \\
\text { cigarretes per } \\
\text { day) }\end{array}$ \\
\hline
\end{tabular}




\begin{tabular}{|c|c|c|c|c|c|}
\hline 4 & $\begin{array}{l}\text { Sporting } \\
\text { habit }\end{array}$ & $\begin{array}{l}\text { Ideally sporting habit } \\
\text { is doing a certain } \\
\text { exercise with an } \\
\text { average time of } 30 \\
\text { minute }\end{array}$ & & $\begin{array}{c}\text { Questionnair } \\
\text { esand } \\
\text { interview }\end{array}$ & $\begin{array}{l}\text { 1. Never } \\
\text { exercise, } \\
\text { never doing } \\
\text { any exercise. } \\
\text { 2. Non-ideal } \\
\text { exercise, } \\
\text { doing a } \\
\text { certain } \\
\text { exercise less } \\
\text { than } 3 \text { times a } \\
\text { week and } 30 \\
\text { minutes a } \\
\text { day. } \\
\text { 3. Ideal exercise, } \\
\text { doing a } \\
\text { certain } \\
\text { exercise at } \\
\text { least } 3 \text { times a } \\
\text { week and } 30 \\
\text { minutes a } \\
\text { day. }\end{array}$ \\
\hline \multicolumn{6}{|c|}{ Dependent Variables } \\
\hline 1. & $\begin{array}{l}\text { CHD } \\
\text { occurren } \\
\text { ce }\end{array}$ & $\begin{array}{l}\text { Cardivascular disorder } \\
\text { is characterized by a } \\
\text { typical chest pain- } \\
\text { felt like a heavy } \\
\text { pressure on chest- } \\
\text { and the increased of } \\
\text { cardiac enzym. It can } \\
\text { be screened using } \\
\text { electrocardiography. }\end{array}$ & Nominal & $\begin{array}{c}\text { Questionnair } \\
\text { esand } \\
\text { interview }\end{array}$ & $\begin{array}{l}\text { 1. Yes (if have } \\
\text { CHD. } \\
\text { 2. No (if have } \\
\text { no CHD). }\end{array}$ \\
\hline
\end{tabular}

Place the figure as close as possible after the point where it is first referenced in the text. If there is a large number of figures and tables it might be necessary to place some before their text citation.

\subsection{Data Analysis}

Data in this study were obtained from both primary and secondary sources. The primary data were directly obtained from respondents who filled-in the questionnaires, while the secondary data were obtained from available reports and documents owned by the hospital. The data processing was involved a series of following steps, i.e.:

1) Editing. Recheck and further investigate all the collected data and fix the failures and the shortcomings one in order to improve the quality of data.

2) Coding. Give numerical codes for the data which consisted of several categories.

3) Entry. Enter the data into computer to be analyzed in accordance with their respective variables 
4) Cleaning. Identify and correct errors of the entered data by observing the distribution or deployment frequency of each studied variable.

5) Tabulating. Put the data in a frequency distribution table in order to facilitate the analysis, data processing and conclusions to be made.

The collected data were processed using computer software and further analyzed to see the distribution overview of each variable, as well as to test the research hypothesis for observing the relationship between independent and dependent variables and finding a fit model for CHD occurrence detection. A series of analysis carried out in this research are as follow:

1) Univariate analysis. Analyze each of research variables in order to find out their distribution [22].

2) Bivariate analysis. Examine the relationship between two variables, independent and dependent, using chi-square test [9]. In this research, the analysis was also used in selecting potential independent variables to be included into further analysis, that is variables with $\mathrm{p}<0.25$ (Mickey and Greenland in Hosmer and Lemeshow, 2000). It was also used further in obtaining OR value and $95 \% \mathrm{CI}$ as well as in making decisions with significance level of $0.05(\alpha=5 \%)$ according to the following provisions:

- If $p$ value is $\leq 0.05$, the relationship is significant;

- If $p$ value is $>0.05$, the relationship is insignificant.

3) Multivariate analysis. Simultaneously observe the relationship between several independent variables and several dependent variables. In this research, the multivariate analysis used in analyzing the data was Multiple Logistic Regression Test. The intention of this test is to obtain the most appropriate model which illustrates the influential determinants on CHD occurrences (Ariawan, 2008). The regression formula is as follow:

$\gamma=\ln \frac{p}{1-p}=\beta o+\beta_{1} x_{1}+\ldots \ldots+\beta_{i} x_{i}$

where $\mathrm{p}$ denotes CHD occurrences.

$$
p=\frac{1}{1+e^{-\left(\beta_{0}+\beta_{1} x_{1} \ldots . .+\beta_{i} x_{i}\right.}}
$$

where $\beta_{i}=0,1,2, \ldots, n$ denotes the parameters of logistic regression model and $x_{i}=1,2$, $3, \ldots, n$ denotes independent variables observed.

\section{Results and Discussion}

\subsection{Univariate Analysis}

Characteristic of Respondents 
Table 2. Distribution of characteristic frequency of respondents

\begin{tabular}{|c|c|c|c|c|c|}
\hline \multirow{2}{*}{ No } & \multirow{2}{*}{ Characteristics } & \multicolumn{2}{|c|}{ Case } & \multicolumn{2}{|c|}{ Control } \\
\hline & & $\mathbf{N}$ & $\%$ & $\mathbf{n}$ & $\%$ \\
\hline \multirow[t]{4}{*}{1} & Age & & & & \\
\hline & - $30-45$ years old & 19 & 20.7 & 32 & 34.8 \\
\hline & - $46-60$ years old & 60 & 65.2 & 43 & 46.7 \\
\hline & - $\quad 61-75$ years old & 13 & 14.1 & 17 & 18.5 \\
\hline \multicolumn{2}{|r|}{ Total } & 92 & 100 & 92 & 100 \\
\hline \multirow[t]{4}{*}{2} & Level of Education & & & & \\
\hline & $\begin{array}{l}\text { - Low (Elementary } \\
\text { School) }\end{array}$ & 20 & 21.7 & 13 & 14.1 \\
\hline & - Middle (High School) & 50 & 54.3 & 65 & 70.7 \\
\hline & - High (University) & 22 & 23.9 & 14 & 15.2 \\
\hline \multicolumn{2}{|r|}{ Total } & 92 & 100 & 92 & 100 \\
\hline \multirow[t]{4}{*}{3} & Type of Occupation & & & & \\
\hline & - Farmer & 17 & 18.5 & 22 & 23.9 \\
\hline & - Enterpreneur & 52 & 56.5 & 58 & 63.0 \\
\hline & - Civil Servant & 23 & 25.0 & 12 & 13.0 \\
\hline \multicolumn{2}{|r|}{ Total } & 92 & 100 & 92 & 100 \\
\hline
\end{tabular}

The underlying characteristics of respondents in this research were classified based on three categories, i.e.: age, level of education and type of occupation (Table 2). According to the table, CHD cases mostly occurred in age $46-60$ years $(65,2 \%)$. Similarly, the control group were also found to be vulnerable for people aged 46-60 tahun $(46,7 \%)$. With regard to level of education, both CHD and control group were found to be mostly experienced by those who were with middle level of education, respectively $54,3 \%$ and $70,7 \%$. It happened the same to type of occupation, where the CHD and the control group were mostly had by those who work as enterpreneur, respectively $56,5 \%$ and $63,0 \%$.

\section{Respondents Behaviors and CHD Occurrence}

Table 3. Influence of respondents' behaviors on CHD occurrence

\begin{tabular}{|c|c|c|c|c|c|}
\hline \multirow{2}{*}{ No } & \multirow{2}{*}{ Respondents Behaviors } & \multicolumn{2}{|c|}{ Case } & \multicolumn{2}{|c|}{ Control } \\
\hline & & $\mathbf{N}$ & $\%$ & $\mathbf{N}$ & $\%$ \\
\hline \multirow[t]{4}{*}{1} & Eating behavior & & & & \\
\hline & - Frequently & 62 & 67.4 & 20 & 21.7 \\
\hline & - Moderate & 18 & 19.6 & 37 & 40.2 \\
\hline & - Infrequently & 12 & 13.0 & 35 & 38.0 \\
\hline \multicolumn{2}{|r|}{ Total } & 92 & 100 & 92 & 100 \\
\hline \multirow[t]{4}{*}{2} & Smoking habit & & & & \\
\hline & Heavy smoker & 71 & 77.2 & 23 & 25.0 \\
\hline & Moderate smoker & 15 & 16.3 & 32 & 34.8 \\
\hline & Light smoker & 6 & 6.5 & 37 & 40.2 \\
\hline
\end{tabular}




\begin{tabular}{|c|l|c|c|c|c|}
\hline \multicolumn{2}{|c|}{ Total } & 92 & $\mathbf{1 0 0}$ & $\mathbf{9 2}$ & $\mathbf{1 0 0}$ \\
\hline $\mathbf{3}$ & Sporting habit & \multicolumn{5}{|c|}{} \\
\hline & Never exercise & 68 & 73.9 & 27 & 29.3 \\
\hline & Non-ideal exercise & 17 & 18.5 & 36 & 39.1 \\
\hline & Ideal exercise & 7 & 7.6 & 29 & 31.5 \\
\hline \multicolumn{7}{|c|}{ Total } & $\mathbf{9 2}$ & $\mathbf{1 0 0}$ & $\mathbf{9 2}$ & $\mathbf{1 0 0}$ \\
\hline
\end{tabular}

The table 3 above presents the influence of respondents' behaviors on CHD occurrence amongst the outpatients at Heart Polyclinic Zainoel Abidin Hospital using univariate analysis. The behaviors are relevant to eating behavior, smoking habit and sporting habit. In regard to eating behavior, the case group was dominated by people who have frequent meals $(67.4 \%)$ while the control group was dominated by those with moderate eating habit $(40.2 \%)$. Regarding the smoking habit, $77.2 \%$ persons in the case group were identified as heavy smokers, while in the contrary, $40.2 \%$ persons in the control group were identified as light smokers. To the sporting habit, mostly people $(73 \%)$ in the case group were known to had never exercises, while in the control group mostly of them $(39.1 \%)$ were had non-ideal exercise.

\subsection{Bivariate Analysis}

The Influence of Respondents Behavior on CHD Occurrence

Table 4. Influence of respondents behavior on CHD occurrence

\begin{tabular}{|c|c|c|c|c|c|c|}
\hline \multirow{2}{*}{ No } & \multirow{2}{*}{ Respondents Behavior } & \multicolumn{2}{|c|}{ Case } & \multicolumn{2}{|c|}{ Control } & \multirow{2}{*}{$\begin{array}{c}p \\
\text { value }\end{array}$} \\
\hline & & $\mathbf{N}$ & $\%$ & $\mathbf{N}$ & $\%$ & \\
\hline \multirow[t]{4}{*}{1} & Eating behavior & & & & & \\
\hline & - Frequently & 62 & 67.4 & 20 & 21.7 & \multirow{4}{*}{0.000} \\
\hline & - Moderate & 18 & 19.6 & 37 & 40.2 & \\
\hline & - Infrequently & 12 & 13.0 & 35 & 38.0 & \\
\hline \multicolumn{2}{|r|}{ Total } & 92 & 100 & 92 & 100 & \\
\hline \multirow[t]{4}{*}{2} & Smoking habit & & & & & \\
\hline & Heavy smoker & 71 & 77.2 & 23 & 25.0 & \multirow{4}{*}{0.000} \\
\hline & Moderate smoker & 15 & 16.3 & 32 & 34.8 & \\
\hline & Light smoker & 6 & 6.5 & 37 & 40.2 & \\
\hline \multicolumn{2}{|r|}{ Total } & 92 & 100 & 92 & 100 & \\
\hline \multirow[t]{4}{*}{3} & Sporting habit & & & & & \\
\hline & Never exercise & 68 & 73.9 & 27 & 29.3 & \multirow{4}{*}{0.000} \\
\hline & Non-ideal exercise & 17 & 18.5 & 36 & 39.1 & \\
\hline & Ideal exercise & 7 & 7.6 & 29 & 31.5 & \\
\hline & Total & 92 & 100 & 92 & 100 & \\
\hline
\end{tabular}


According to the chi-square test, this study concluded that:

1) There is a significant influence between eating behavior and CHD occurrence as mostly CHD patients in this research were dominated by those who have frequent meals $(67.4 \%)$;

2) There is a significant influence between smoking habit and CHD occurrence as mostly CHD patients in this research were identified as heavy smokers (77.2\%);

3) There is also a significant influence between sporting habit and $\mathrm{CDH}$ occurrence as mostly CHD patients in this research were known to had never exercise (73.9\%).

\subsection{Multivariate Analysis}

After multivariate analysis for observing the relationship of each variable on CHD occurrence was done, the multivariate analysis was then carried out for determining the most dominant variable that influence the CHD occurrence by using Multiple Logistic Regression Model.

The variables with $p$ value of $<0.25$ were then included into regression test. According to the chi square test result (Table 4), all the tested variables were had $\mathrm{p}<0.25$, thus they all were able to be included to the multivariate analysis. Detail is shown below (Table 5).

Table 5. Variables selection result

\begin{tabular}{lcc}
\hline \multicolumn{1}{c}{ Variable } & p value & Description \\
\hline Eating behavior & 0.000 & $\mathrm{P}<0.25$ \\
Smoking habit & 0.000 & $\mathrm{p}<0.25$ \\
Sporting habit & 0.000 & $\mathrm{P}<0.25$ \\
\hline
\end{tabular}

Tabel 6. Multiple Logistic Regression Model and CDH occurrences

\begin{tabular}{cccccc} 
Variabel & \multirow{2}{*}{ B } & \multirow{2}{*}{ Sig. } & OR & \multicolumn{2}{c}{$\mathbf{9 5 \%}$ C.I } \\
\cline { 5 - 7 } & & & & Lower & Upper \\
\hline Eating behavior & 1.394 & 0.000 & 4.031 & 2.316 & 7.016 \\
Smoking habit & 1.662 & 0.000 & 5.269 & 2.962 & 9.373 \\
Sporting habit & 1.438 & 0.000 & 4.214 & 2.322 & 7.647 \\
\hline Constant & $\mathbf{7 . 7 3 6}$ & $\mathbf{0 . 0 0 0}$ & $\mathbf{0 . 0 0 0}$ & & \\
\hline
\end{tabular}

According to multivariate analysis, the most dominant variable that influence CHD occurrence is smoking habit ( $\mathrm{p}=0.000$; $\mathrm{OR}=5.3$ ) which means that $\mathrm{CHD}$ risk in heavy smoker is 5.3 times higher than in light smokers.

\subsection{Discussion}

\section{The Influence of Eating Behavior on CHD Occurrence}

The research results shows that there is a significant influence between eating behavior and CHD occurrence $(\mathrm{p}=0.000)$. The majority patients of CHD (case group) were those who have frequent meals $(67.4 \%$ ), while the non-CHD patients (control group) were those who have moderate eating behavior $(40,2 \%)$. 
Ridwan (2009) stated that almost $90 \%$ of diseases, both degenerative and cardiovascular, are caused by the poor eating habits in people daily life. Foods recommended to avoid are those that contain high saturated fat and bad cholesterol like meat and fast foods.

According to Ratna et. al [19] eating behavior plays an important role in CHD prevention and treatment. People consuming 35 grams fiber foods per day have lower risks of CHD compared to people who consume less than 15 grams fiber per day. Low calorie foods, like seeds, fruits and vegetables can lowering cholesterol and maintaining healthy weight. Most of cardiovascular patients are overweight and have high blood cholesterol. To lose the weight, the calorie intake must be cut back by doing more physical activities.

\section{The Influence of Smoking Habit on CHD Occurrence}

The result of this study shows that there is a significant influence between smoking habit and CHD occurrence $(\mathrm{p}=0.000)$. According to the results, $77.2 \%$ persons in the case group were identified as heavy smokers, while in the contrary, $40.2 \%$ persons in the control group were identified as light smokers. In addition, the multivariate analysis was clearly suggested that smoking habit is the most dominant variable that influences CHD occurrence $(p=0.000 ; \mathrm{OR}=5.3$, which means that heavy smokers are 5.3 times have increased risks of CHD). This result is in line with the previous researches conducted by Lewis et al. (2007) and Smeltzer and Bare (2002) which suggested that heavy smokers were likely to have 2-4 times higher risks of CHD than the non-smokers.

Cigarrete contains hundreds of harmful chemical substances, like tar, nicotine, carbonmonoxide, etc., that can reduces oxygen supply to the heart, increases blood and pulse pressure, decreases HDL cholesterol level, clots blood and causes endotel dysfunction.

Gray et al. (2002) stated that CHD risk rises with the increasing of blood pressure. This study suggested that blood pressure levels ranging from 120-129 mmHg systolic/80-84 $\mathrm{mmHg}$ diastolic were associated with two times higher risk of cardiovascular disease compared to levels of less than $120 / 80 \mathrm{mmHg}$.

\section{The Influence of Sporting Habit on CHD Occurrence}

The result of this study also shows that there is a significant influence between sporting habit and CHD occurrence as mostly CHD patients in this research were known to had never exercise (73.9\%), while the non-CHD patients were mostly had non-ideal exercise (39.1). This is in accordance with Bender et al. [2] research results presented in their Cardiology book which indicated that there is a strong relationship between physical activity and CHD occurrence. The more exercises people do, the lesser CHD risk they have. Kabo (2008) stated that lack physical activity causes various diseases, including CHD. In regard to the disease, inactive people are 1.9 times more likely to develop CHD than those who are active.

According to Kusmana et. al [13], the frequency of physical activity/exercise determines its quality. The best exercise frequency that gives optimal result is carried out in a regular basis, 3- 6 times a week. The longer the exercise, the more the blood supplied to the heart and the more oxygen get distributed to the whole body. Having a 30-minutes exercise per day can double the effect, not only increases the blood supply but also turn off the body's generation of fat and cholesterol which eventually decreased CHD risk. 


\section{Conclusion and Suggestions}

This research was intended to observe CHD patients behaviors which are viewed from socio-cultural aspect of Aceh society in Zainoel Abidin Hospital Banda Aceh with the following conclusions:

1) There is a significant influence between eating behavior and CHD occurrence $(\mathrm{p}=0.000)$;

2) There is a significant influence between smoking habit and CHD occurrence $(\mathrm{p}=0.000)$;

3) There is also a significant influence between sporting habit and CHD occurrence $(\mathrm{p}=0.000)$.

According to the results, we also provide several suggestions as follow:

1) Health workers are expected to increase health promotion in order to improve the quality of life of people, especially in elderly people, by adopting a healthy lifestyle and avoiding CHD risk factors;

2) People are also suggested to take regular lipid profile check up and keep off smoking habit in order to do early prevention of CHD.

\section{References}

1. Backer $\mathrm{G}$, et al. Overweight and obessity:a major challenge for coronary heart disease secondary prevention in clinical practice in Europe,European Heart Journal 2002; 21: 808-813, (2002)

2. Bender J. R, Russel K. S, Rosenfeld L. E, and Chaundry S,. Oxford American Handbook of Cardiology. New York: Oxford. p. 256-260,( 2011)

3. Dahlan, S.M, Analisis Multivariat Regresi Logistik. PT. Epidemiologi Indonesia. Jakarta, (2012)

4. Dalusung-Angosta, A. Coronary Heart Desease Knowledge and Risk Faktors among Filipino-Americans connected to Primary Care Services. University of Hawai at Manoa. ProQuest Dissrtations and Theses, (2010)

5. Gray, H.H, Dawkins, K.D., Morgan, J. M \& Simpson, I.A, Lectures Note on Cardiology ( $4^{\text {th }}$ ed). Southampton. Blackwell Science Ltd, (2002)

6. Hastono, S.P,; Sabri, Luknis,. Statistik Kesehatan. Penerbit Raja Grafindo, Jakarta, (2006)

7. Hendramartono,. Obesitas sebagai faktor risiko penyakit kardiovaskular. Surabaya. Majalah Kedokteran UDAYANA. Volume 33, (2002)

8. Honigmann, John, J.. The World of Man Dalam Pengantar Ilmu Antropologi. Rineka Cipta. Jakarta, (1959)

9. Hosmer, David .W, and Lemeshow, Stanley,. Applied Logistic Regression $2^{\text {nd }}$. Ed.John Wiley \& Sons.Inc., New York, (2000)

10. Ismail, TH jafar, FH Jafari, F White, AM Faruqui, N Chaturvedi, Risk factors for non-fatal myocardial infarction in young south asian adults, Heart on Line 2004; 90: $259-263$ 
11. Kabo, P.. Mengungkap Pengobatan Penyakit Jantung Koroner : Kesaksian seorang ahli jantung dan ahli obat. Gramedia Pustaka Utama. Jakarta, (2008)

12. Safaat, Bagaimana Menggunakan Obat-Obat Kardiovaskuler Secara Rasional. Jakarta : Balai Penerbit FKUI,( 2010)

13. Kusmana D. dan Hanafi M.,. Patofisiologi Penyakit Jantung Koroner In : Buku Ajar Kardiologi Fakultas Kedokteran Universitas Indonesia, 1st ed, Jakarta : 159-165, (1996)

14. Lemeshow, S,. Besar Sampel dalam Penelitian Kesehatan. Penerjemah Pramono, Gadjah Mada University Press, Yogyakarta, (1997)

15. Lapau, Buchari,. Metode Penelitian Kesehatan : Metode Ilmiah Penulisan Skripsi, Tesis dan Disertasi. Buku OBOR. Jakarta, (2013)

16. Lewis, S. L., Heitkemper, M.M., Dirksen, S.R., O’brien, P.G. \& Bucher, L, Medical Surgical Nursing : Assesment and Management of Clinical Problems. Servent Edition. Volume 2. Mosby Elsevier, (2007)

17. Lipoeta, I.,. Zat Gizi dan Makanan Pada Penyakit Kardiosvascular, Andalah InsistPress. Yogyakarta, (2006)

18. Notoatmodjo.. Promosi Kesehatan Teori \& Aplikasi. PT Rineka Cipta, Jakarta, (2010)

19. Ratna,. Penyakit- Penyakit Mematikan. Nuha Medika. Yogyakarta, (2013)

20. Riskesdes,. Penyajian Pokok-Pokok Hasil Riset Kesehatan Dasar. Badan Penelitian dan Pengembangan Kesehatan Kementerian Kesehatan RI. Jakarta, (2007)

21. Penyajian Pokok-Pokok Hasil Riset Kesehatan Dasar. Badan Penelitian dan Pengembangan Kesehatan Kementerian Kesehatan RI. Jakarta, (2013)

22. Riyanto, A, Pengolahan dan Analisis Data Kesehatan. Nuha Medika. Yogyakarta (2010)

23. Smeltzer, C, \& Bare, B.G,. Buku Ajar Keperawatan Medical Bedah : Brunner \& Suddarth. Edisi 8.Volume 2. Jakarta. EGC, (2002)

24. World Health Organization (WHO), Cardiovascular Disease. Available from:www.who.int/mediacentre, (2011) 